\title{
PENERAPAN SISTEM INFORMASI MANAJEMEN DI SEKOLAH
}

\section{Oleh}

\section{HARI RAMADANI}

17002016

\section{UNIVERSITAS NEGERI PADANG}

Hariramadani98@gmail.com

\begin{abstract}
ABSTRAK
Pada penulisan kali ini bertujuan untuk mengetahui penerapan sistem informasi manajemen di sekolah. Sistem informasi manajemen dapat membantu sekolah dalam mengumpulkan dan mengolah data yang dapat digunakan sebagai informasi untuk pelayana di sekolah tersebut. Dengan adanya sistem informasi manajemen sekolah dapat mengumpulkan dan mengolah data secara valid dan akurat sehingga informasi yang diberikan kepada pengguna memiliki kuantitas dan kualitas yang tepat.
\end{abstract}

Kata kunci: sistem informasi manajemen, penerapan sistem informasi

\section{PENDAHULUAN}

Dalam menghadapi globalisasi pada saat sekarang ini, pendidikan di indonesia harus secepatnya merubah diri dalam meningkatkan sistem informasi untuk menunjang daya saing sumber daya manusia yang dihasilkan oleh lembaga pendidikan tersebut.

Sistem informasi sangat dibutuhkan oleh lembaga pendidikan, khususnya dalam meningkatkan kelancaran informasi dalam pendidikan, kontrol kualitas dan menciptakan kerja sama dengan pihak lain yang dapat meningkatkan nilai lembaga tersebut. 
Menurut sabandi dalam (Agustiandra \& Sabandi, 2019) dengan pemanfaatan ilmu pengetahuan, dan teknologi yang semakin berkembang dapat meningkatkan kualitas pembelajaran.

Oleh karena itu penting sebuah sekolah menerapkan sistem informasi manajemen agar mampu memberikan layanan informasi yang sesuai dengan kebutuhan pengguna serta mudah digunakan pada saat informasi tersebut dibutuhkan.

\section{PEMBAHASAN}

\section{A. Pengertian Sistem Informasi Manajemen}

Menurut (Hartono, 2013) Sistem informasi manajemen adalah sebuah sistem, yaitu rangkaian terorganisasi dari sejumlah/komponen yang secara bersama-sama berfungsi atau bergerak menghasilkan informasi untuk digunakan dalam perusahaan.

Menurut Mc.Leod dalam (Yakub, 20012) Sistem Informasi Manajemen didefinisikan sebagai suatu sistem berbasis komputer yang menyediakan informasi bagi beberapa pemakai dengan kebutuhan serupa.

Menurut komarudin dalam (Rochaety, 2009) Sistem Informasi Manajemen adalah suatu sistem informasi yang memungkinkan pimpinan organisasi mendapatkan informasi dengan kuantitas dan kualitas yang tepat untuk digunakan dalam proses pengambilan keputusan

Menurut Robert W. H dalam (Rochaety, 2009) SIM adalah sistem yang dirancang untuk menyajikan informasi pilihan yang berorientasi kepada keputusan yang diperlukan oleh manajemen guna merencanakan, mengawasi, dan menilai aktivitas organisasi yang dirancang dalam kerangka kerja yang menitik beratkan pada perencanaan keuntungan, peencanaan penampilan dan pengawasan pada semua tahap.

Dari uraian diatas dapat disimpulkan bahwa Sistem Informasi Manajemen adalah suatu sistem yang menyediakan informasi bagi beberapa pemakai dengan kuantitas dan kualitas yang tepat untuk digunakan dalam proses pengambilan keputusan. 


\section{B. Tujuan Sistem Informasi Manajemen}

1. Menyediakan suatu informasi yang dapat digunaka dalam pengambilan keputusan

2. Untuk menyediakan yang akan digunakan dalam suatu perencanaan, pengendalian dan pengevaluasian.

3. Untuk menyediakan informasi bagi beberapa pemakai dengan kualitas dan kuabtitas yang jelas.

Sedangkan menurut (Agustiandra \& Sabandi, 2019) tujuan sistem informasi manajemen adalah untuk menunjang proses pengambilan keputusan serta memperbaiki proses perencanaan dan pengawasan.

\section{Manfaat Sistem Informasi Manajemen}

1. SIM dapat mengantisipasi konsekuensi ekonomis dari sebuah sistem inormasi dan teknologi baru

2. Dengan sistem informasi manajemen dapat mengembangkan perencaan yang efektif

3. Dengan sistem informasi manajemen dapat mengelolah seluruh informasi-informasi yang ada atau terkait pada organisasi tersebur

Sedangkan menurut (Wiguna, 2017) dengan adanya pemanfaatan sistem informasi manajemen sekolah, organisasi pendidikan akan merasakan beberapa manfaat seperti: Tersedianya sistem pengelolaan data dan informasi pendidikan, Terintegrasinya data dan informasi pendidikian untuk mendukung proses pengambilan keputusan dan tersedianya data inormasi pendidikan yang lengkap bagi seluruh stakeholders yang bergabung dalam sistem pendidikan. Sistem informasi manajemen sekolah digunakan sebagai alat bantu pengambilan keputusan dan oleh pihak lain yang bergabung dalam inter-organizational inormation system, sehingga organisasi pendidikan dapat berinteraksi dengan pihak berkepentingan (stakeholders).

\section{Implementasi Sistem Informasi Mananejem di sekolah}

Sekolah dikatakan berhasil apabila mampu memenuhi semua kebutuhan pelanggan (peserta didik, pendidik, orang tua dan masyrakat). SIM sebagai pendukung 
organisasi pedidikan harus mampu memberikan layanan informasi yang sesuai dengan kebutuhan pengguna serta mudah didapatkan. Secara umum layanan informasi dapat diartikan kegiatan yang hasilnya ditujukan untuk kepentingan orang lain, perorangan, kelompok dan masyrakat.

Layanan informasi pada suatu sekolah merupakan upaya untuk mencapai kepuasan pengguna, dengan cara memenuhi kebutuhan pengguna dan melakukan perbaikan terus-menerus terhadap layanan yang diberikan. Layanan informasi tidak hanya diberikan kepada peserta didik dan orang tua saja, tetapi SIM yang diterapkan di sekolah meliputi: sistem informasi keuangan, sistem informasi sarana dan prasarana, sistem informasi kurikulum serta informasi kesiswaan.

Dalam menigkatkan layanan pada suatu sekolah kita perlu menerapkan fungsi sistem informasi manajemen. Dengan adanya sistem informasi manajemen, sekolah dapat memanfaatkanya untuk memberikan penyajian data yang akurat, relevan dan tepat waktu. Secara otomatis sistem informasi manajemen dapat membantu memberikan informasi kepada pihak yang berkepentingan secara cepat dan tepat sasaran berdasarkan informasi yang terintergrasi dalam sistem manajemen.

Berikut adalah contoh salah satu implementasi sistem informasi manajemen di sekolah

\section{E-Learning}

E-Learning merupakan proses pembelajaran yang menggunakan teknologi informasi yang dapat diakses melalui internet atau online. Dengan adnya E-leaning peserta didika dan pendidik dapat melakukan proses kegiatan pembelajaran secara jarak jauh atau online tanpa melakukan pembelajaran dengan tatp muka atau dikelas.

\section{KESIMPULAN}

Sistem Informasi Manajemen adalah suatu sistem yang menyediakan informasi bagi beberapa pemakai dengan kuantitas dan kualitas yang tepat untuk digunakan dalam proses pengambilan keputusan.

Dalam menigkatkan layanan pada suatu sekolah kita perlu menerapkan fungsi sistem informasi manajemen. Dengan adanya sistem informasi manajemen, sekolah dapat 
memanfaatkanya untuk memberikan penyajian data yang akurat, relevan dan tepat waktu. Secara otomatis sistem informasi manajemen dapat membantu memberikan informasi kepada pihak yang berkepentingan secara cepat dan tepat sasaran berdasarkan informasi yang terintergrasi dalam sistem manajemen.

salah satu contoh implementasi sistem informasi manajemen di sekolah

1. E-Learning

\section{DAFTAR PUSTAKA}

Agustiandra, V., \& Sabandi, A. (2019). Persepsi Guru Terhadap Penerapan Sistem Informasi Manajemen Akademik Di Sekolah Menengah Kejuruan (Smk) Negeri 3 Padang. Jurnal Bahana Manajemen Pendidikan, 8(I), 1-8. Retrieved from http://ejournal.unp.ac.id/index.php/bahana/article/view/103704

Hartono, B. (2013). Sistem Informasi Manajemen Berbasis Komputer. Jakarta: PT Rineka Cipta.

Rochaety, e. d. (2009). Sistem Informasi Manajemen Pendidikan. Jakarta: PT Bumi Aksara.

Wiguna, W. (2017). Kinerja Manajerial, Pemanfaatan Sistem Informasi Manajemen Sekolah Dan Efektifitas Implementasi Rencana Stratejik. Jurnal Administrasi Pendidikan UPI, 24(1), 130-140. Retrieved from https://media.neliti.com/media/publications/74616-ID-kinerjamanajerial-pemanfaatan-sistem-in.pdf

Yakub. (20012). Pengantar Sistem Informasi. Yogyakarta: Graha Ilmu. 